\title{
Prevalence of serum vitamin D deficiency and insufficiency in cancer: Review of the epidemiological literature
}

\author{
DIGANT GUPTA, PANKAJ G. VASHI, KRISTEN TRUKOVA, \\ CHRISTOPHER G. LIS and CAROLYN A. LAMMERSFELD \\ Cancer Treatment Centers of America ${ }^{\circledR}$ at Midwestern Regional Medical Center, Zion, IL 60099, USA \\ Received November 1, 2010; Accepted January 17, 2011
}

DOI: $10.3892 /$ etm.2011.205

\begin{abstract}
Vitamin D deficiency has been found to be associated with a variety of cancers, including prostate, multiple myeloma, colorectal and breast cancer. Several studies have shown vitamin D levels to have an inverse relation with cancer mortality, while others have considered it a potential risk factor. Vitamin D is believed to influence cancer prevalence, risk and survival; hence the need to assess vitamin D levels in cancer. Although numerous studies have been conducted to demonstrate vitamin D deficiency as a risk factor for cancer, relatively few have studied its prevalence. Moreover, studies estimating prevalence differ from each other, with respect to study population, sample size, study design, definition of vitamin $\mathrm{D}$ deficiency used and method of vitamin D assessment (with most studies limited to one particular type of cancer with relatively small sample sizes). Therefore, we qualitatively reviewed the epidemiological evidence in the oncology literature on the prevalence of vitamin D deficiency and insufficiency as measured by serum vitamin D concentrations.
\end{abstract}

\section{Contents}

1. Introduction

2. Search strategy and selection criteria

3. Quality assessment

4. Studies on deficiency and insufficiency of serum vitamin D in breast cancer

5. Studies on deficiency and insufficiency of serum vitamin D in colorectal cancer

6. Studies on deficiency and insufficiency of serum vitamin D in other and multiple cancer sites

7. Discussion

Correspondence to: Dr Digant Gupta, Cancer Treatment Centers of America ${ }^{\circledR}$, at Midwestern Regional Medical Center, Office of Clinical Research, 2520 Elisha Avenue, Zion, IL 60099, USA

E-mail: gupta_digant@yahoo.com

Key words: vitamin D, deficiency, cancer, epidemiology

\section{Introduction}

Vitamin D is the prehormone important for maintaining normal calcium homeostasis and mineralization of the skeleton. Humans acquire vitamin D from exposure to sunlight, from their diet and from dietary supplements (1). Vitamin D produced in the skin upon sun exposure or ingested from the diet is converted in the liver to 25-hydroxyvitamin D [25(OH) $\mathrm{D}$, the major circulating form of vitamin D used for evaluating the vitamin D status of patients. $25(\mathrm{OH}) \mathrm{D}$ is hydroxylated in the kidneys to form the biologically active metabolite 1,25dihydroxyvitamin $\mathrm{D}\left[1,25(\mathrm{OH})_{2} \mathrm{D}\right](1,2)$.

Although the biologically active form of vitamin $\mathrm{D}$ is $1,25(\mathrm{OH})_{2} \mathrm{D}$, it is not considered a good biomarker due to its short half-life and tight homeostatic control (3). Serum 25(OH) $\mathrm{D}$ is an excellent biomarker of vitamin D status, representing both cutaneous synthesis and dietary intake (4). Adequate levels of vitamin D depend on age and therefore definitions of vitamin D deficiency vary. The appropriate thresholds for vitamin D deficiency are debated $(4,5)$. The most widely accepted optimal level of serum $25(\mathrm{OH}) \mathrm{D}$ is $35-55 \mathrm{ng} / \mathrm{ml}$. One study showed that for all health-related end points, the most advantageous serum levels for $25(\mathrm{OH}) \mathrm{D}$ appear to be at least $30 \mathrm{ng} / \mathrm{ml}$, and for cancer prevention desirable levels are between 36 and $48 \mathrm{ng} / \mathrm{ml}$ (6). The average older man and woman need intakes of at least 20-25 mcg (800-1,000 IU) per day of vitamin D to reach a serum 25(OH)D level of $30 \mathrm{ng} / \mathrm{ml}$.

Brain, prostate, breast and colon tissues, among others, as well as immune cells, have a vitamin $\mathrm{D}$ receptor (VDR) and respond to $1,25(\mathrm{OH})_{2} \mathrm{D}$, the active form of vitamin $\mathrm{D}$. In addition, some of these tissues and cells express the enzyme 25-hydroxyvitamin D-1 $\alpha$-hydroxylase that converts $25(\mathrm{OH}) \mathrm{D}$ to $1,25(\mathrm{OH})_{2} \mathrm{D}(7,8)$. The active form of vitamin $\mathrm{D}$ has been shown to exert potent cell regulatory effects in cells other than those involved in calcium homeostasis. The effects are thought to be mediated through the VDR (9). Binding of VDR by $1,25(\mathrm{OH})_{2} \mathrm{D}$ leads to multiple cellular effects, including induction of differentiation and apoptosis $(10,11)$ and inhibition of proliferation (12), angiogenesis (13) and metastatic potential $(14,15)$. Thus, vitamin D is believed to play an important role in the etiology and treatment of cancer.

Vitamin D deficiency has been found to be associated with a variety of cancers, including prostate $(16,17)$, multiple myeloma, colorectal and breast cancer (18). Certain studies 
have shown vitamin $\mathrm{D}$ levels to have an inverse relation with cancer mortality (19-25), while others have considered it a potential risk factor. Higher vitamin D concentrations are associated with a 3-fold decreased risk for pancreatic cancer (highest vs. lowest quintile, $>26.2$ vs. $<12.8 \mathrm{ng} / \mathrm{ml}$ ) (26). Grant demonstrated that much of the geographic variation in cancer mortality rates in the US can be attributed to variations in solar UV-B radiation exposure. Clearly, improving vitamin D status appears vital to overall health, particularly in nonsummer months (27). The evidence that higher 25(OH)D levels through increased sunlight exposure or dietary supplement intake inhibit colorectal carcinogenesis is substantial $(28,29)$. The biologic evidence for an anti-cancer role of $25(\mathrm{OH}) \mathrm{D}$ is also strong for prostate cancer, but the epidemiologic data have not been supportive (30). The above data indicate that vitamin D influences cancer prevalence, risk and survival and hence the need to assess vitamin D levels in cancer.

Although numerous studies have been conducted to demonstrate vitamin D deficiency as a risk factor for cancer, relatively few have studied its prevalence. Most of the studies estimating prevalence have been limited to one particular type of cancer with relatively small sample sizes. Therefore, we qualitatively reviewed the epidemiological evidence in the literature on the prevalence of vitamin $\mathrm{D}$ deficiency and insufficiency as measured by serum $25(\mathrm{OH}) \mathrm{D}$ concentrations.

\section{Search strategy and selection criteria}

We performed a systematic search of the literature using the MEDLINE database (January 2000 through May 2010) to identify articles on the prevalence of serum vitamin $D$ deficiency and insufficiency in cancer. We searched using the terms 'cancer/carcinoma' in combination with 'vitamin D deficiency', 'vitamin D insufficiency' and 'serum vitamin D/25(OH)D levels/concentration'. We also searched the bibliographies of the selected studies to identify relevant articles that we might have missed during the primary MEDLINE search. To be included in the review, a study must have been published in English, must have reported on data collected in humans with cancer, must have had measured serum vitamin D or serum $25(\mathrm{OH})$ $\mathrm{D}$ at single or multiple time points and must have utilized any of the following study designs (case-control, cohort, crosssectional, prospective, retrospective, case series, longitudinal, clinical trial). There were no restrictions according to age, ethnicity, type or stage of cancer. As we were interested in empirical reports that had investigated the prevalence of serum vitamin $\mathrm{D}$ deficiency and insufficiency in cancer, we did not include letters and meeting abstracts. All studies reviewed in this report are summarized in tables under separate headings and arranged chronologically by the year of publication.

\section{Quality assessment}

Although we did not formally rate the quality of reports we reviewed, we recorded and presented information on variables that may reflect the quality of reporting. The variables included years of data collection, study design, sample size, cancer type and stage, definition of vitamin D deficiency used, vitamin D assessment method, prevalence reported and supplementation recommended.

\section{Studies on deficiency and insufficiency of serum vitamin $D$ in breast cancer}

Table I describes studies investigating the deficiency and insufficiency of serum vitamin $\mathrm{D}$ in patients with breast cancer. The studies are arranged chronologically by the year of publication.

Nogues et al reported a prevalence of $85-92 \%$ of vitamin D deficiency in breast cancer patients. In their study, treatment with $16,000 \mathrm{IU}$ of vitamin D every 2 weeks increased vitamin D plasma levels significantly in $\sim 76.5 \%$ of subjects with baseline vitamin D deficiency (plasma levels $<30 \mathrm{ng}$ / $\mathrm{ml}$ ) over 3 months of follow-up. Notably, in the few subjects that had baseline vitamin D levels $\geq 30 \mathrm{ng} / \mathrm{ml}$, despite being prescribed vitamin D supplements (800 IU), their vitamin D levels did not increase significantly (31). Neuhouser et al assessed serum 25-25(OH)D status and its relationship to breast density in 426 breast cancer survivors. Most participants $(76.8 \%)$ had vitamin D insufficiency or frank deficiency. No association of serum $25(\mathrm{OH}) \mathrm{D}$ with either breast density or breast dense area was observed. It was concluded that, despite the strong association of mammographic density with breast cancer risk, the mechanism is not likely to be mediated by vitamin D (32). Khan et al reported the safety and efficacy of vitamin D supplementation using 50,000 IU weekly on postmenopausal women. In their study, the prevalence of vitamin $\mathrm{D}$ deficiency was $63 \%$. They also studied the effect of vitamin D-ss (standard supplementation) and vitamin D-HD (high dose) supplementation on serum $25(\mathrm{OH}) \mathrm{D}$ levels. Their results suggested that 50,000 IU of vitamin D3, when administered weekly to postmenopausal women starting adjuvant letrozole, resulted in clinically significant improvement in disability from joint symptoms (33).

Crew et al reported a prevalence of $74 \%$ of vitamin D deficiency in breast cancer patients. They also observed that $400 \mathrm{IU}$ of cholecalciferol daily for 1 year increased serum $25(\mathrm{OH}) \mathrm{D}$ levels only modestly, by $<3 \mathrm{ng} / \mathrm{ml}$, in only $15 \%$ of premenopausal women. Although the DRI for vitamin D in premenopausal women is only 200 IU daily, their study suggested that a dose of 400 IU daily was inadequate in breast cancer patients, even to maintain skeletal health, and was probably too low for meaningful anticancer effects (34). Rainville et al observed the vitamin D status in different breast cancer phenotypes: luminal A, luminal B, HER2 ${ }^{+} / \mathrm{ER}^{-}$and triple-negative. When assessing all of the breast cancer patients (91 total), it was found that 54 patients $(62 \%)$ had baseline vitamin D levels in the deficiency range $<32 \mathrm{ng} / \mathrm{ml}$. Thirteen of the fifteen triplenegative breast cancer patients $(87 \%)$ were found to be vitamin $\mathrm{D}$ deficient, prior to initiation of adjuvant therapy. These data may suggest that low vitamin D levels are more prevalent in triple-negative phenotype (35). Waltman et al determined whether serum $25(\mathrm{OH}) \mathrm{D}$ concentrations were below normal ( $<30 \mathrm{ng} / \mathrm{ml}$ ) in 29 breast cancer survivors receiving aromatase inhibitor therapy and whether musculoskeletal symptoms were related to these low vitamin D levels. The mean (SD) serum 25(OH)D level was $25.62(4.93) \mathrm{ng} / \mathrm{ml} ; 86 \%(\mathrm{n}=25)$ had levels $<0 \mathrm{ng} / \mathrm{ml}$. The prevalence of vitamin D insufficiency in this sample was high despite the fact that their mean daily intake of vitamin D supplements was 665 IU and the mean time in the sun in the past week was reported as $39 \min (36)$. 


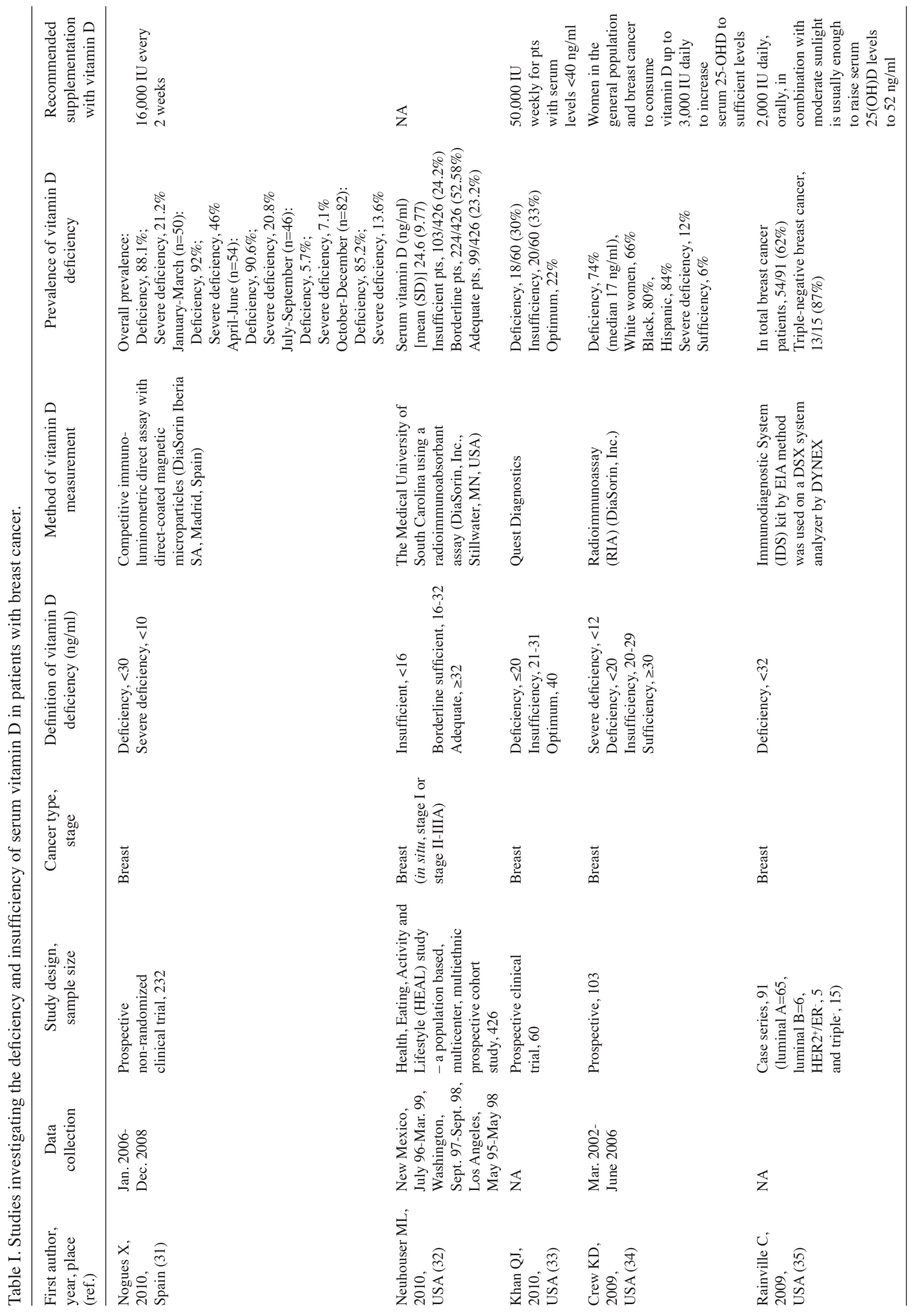




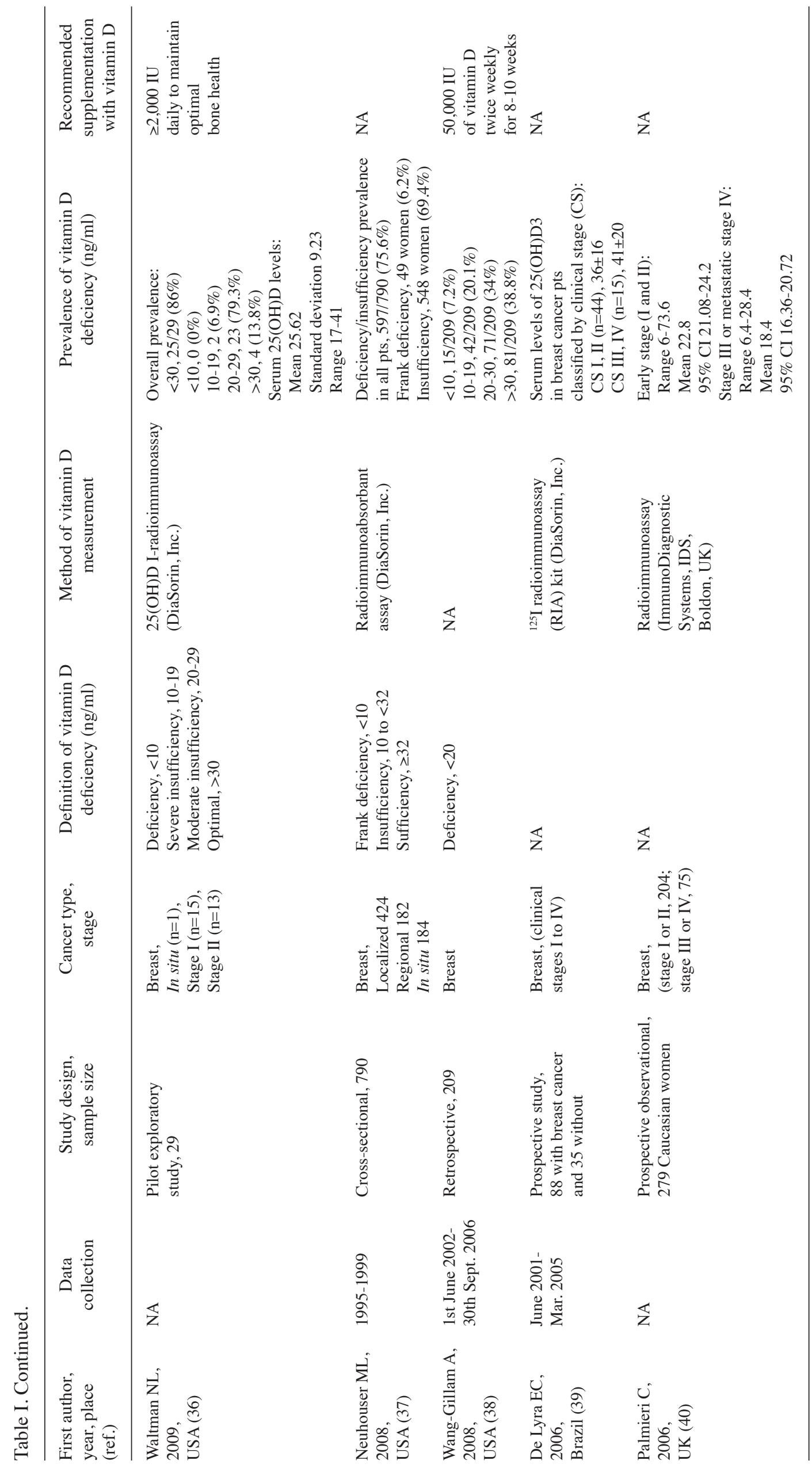


Neuhouser et al described the vitamin D status in a breast cancer survivor cohort of 790 women. Five hundred and ninety-seven $(75.6 \%)$ of the women had low serum $25(\mathrm{OH})$ $\mathrm{D}$, suggesting vitamin D insufficiency of $69.4 \%$ (levels from 10 to $<32 \mathrm{ng} / \mathrm{ml}$ ) and frank deficiency of $6.2 \%$ (levels $<10 \mathrm{ng} /$ $\mathrm{ml})$. Women with localized $(\mathrm{n}=424)$ or regional $(\mathrm{n}=182)$ breast cancer had lower serum $25(\mathrm{OH}) \mathrm{D}$ than did women with in situ disease $(\mathrm{n}=184)(\mathrm{P}=0.05$ and $\mathrm{P}=0.03$, respectively) (37). Wang-Gillam et al examined the prevalence of vitamin D deficiency in 321 breast cancer patients treated with bisphosphonates. Two hundred and nine $(65.1 \%)$ had their $25(\mathrm{OH})$ D levels checked at least once. Of these patients, $57(27.3 \%)$ had a serum 25(OH)D level <20 ng/ml. Only $113(42.3 \%)$ of 267 patients who were prescribed a bisphosphonate for osteoporosis also took a daily vitamin D supplement, and among metastatic bone disease patients, the rate for vitamin D supplementation was even lower at $13.0 \%$. The study hypothesized that low rates of vitamin D supplementation could be one reason for vitamin D deficiency (38). De Lyra et al investigated the serum levels of $25(\mathrm{OH}) \mathrm{D} 3$ and its active form $1,25(\mathrm{OH})_{2} \mathrm{D} 3$ in 88 Brazilian breast cancer patients and 35 women without cancer. Although no differences in $25(\mathrm{OH})$ D3 serum concentration were found, $1,25(\mathrm{OH})_{2} \mathrm{D} 3(40 \pm 21 \mathrm{pg} /$ $\mathrm{ml}$ ) levels in breast cancer patients were lower than in women without cancer $(53 \pm 23 \mathrm{pg} / \mathrm{ml})$. The lack of a difference in the serum levels of $25(\mathrm{OH}) \mathrm{D} 3$ between women with and without breast cancer supports the probability that a low circulating concentration of $1,25(\mathrm{OH})_{2} \mathrm{D} 3$ in breast cancer patients is not attributed to 25(OH)D3 insufficiency (39). Palmieri et al prospectively measured circulating levels of 25(OH)D in 279 Caucasian women with invasive breast cancer, 204 women with early-stage disease and 75 women with locally advanced or metastatic disease. The results depicted that patients with early-stage breast cancer had significantly higher circulating levels of $25(\mathrm{OH}) \mathrm{D}$ (mean serum levels $22.8 \mathrm{ng} / \mathrm{ml}$ ) than those with advanced disease (mean serum levels $18.4 \mathrm{ng} / \mathrm{ml}$ ) $(\mathrm{P}<0.005)(40)$.

\section{Studies on deficiency and insufficiency of serum vitamin $\mathrm{D}$ in colorectal cancer}

Table II describes studies investigating the deficiency and insufficiency of serum vitamin D in patients with colorectal cancer (CRC). The studies are arranged chronologically by the year of publication.

Charalampopoulos et al determined the serum levels of vitamin D metabolites and parathyroid (PTH) in patients with colorectal cancer and found: i) no significant difference in the serum levels of 25(OH)D3 in each Dukes' clinical stage in cancer patients, ii) serum $1,25(\mathrm{OH})_{2} \mathrm{D} 3$ levels decreased with advanced cancer stages, and iii) serum levels of PTH showed a corresponding increase with advanced cancer stages. Low serum levels of $1,25(\mathrm{OH})_{2} \mathrm{D} 3$ on one hand, and increased levels of PTH in patients with colorectal cancer on the other, may be strongly related to the carcinogenetic process (41). Fakih et al carried out a study in the US comprising 315 patients with $\mathrm{CRC}$, where $25-\mathrm{OH}$ vitamin $\mathrm{D}$ status was dichotomized into two categories; 'very low' $(<15 \mathrm{ng} / \mathrm{ml})$ and 'low to normal' (>15 ng/ml). Twenty-nine out of $135(21 \%)$ patients in stage 1 to 3 of CRC had serum levels of vitamin D in the 'very low' category along with 58 out of $180(32 \%)$ patients in stage 4. It was recommended that patients with CRC, particularly those receiving chemotherapy, should be considered for aggressive vitamin D replacement strategies (42). Niv et al demonstrated an inverse correlation between serum levels of the active metabolite of vitamin D and colorectal carcinoma stage. The study compared serum 1,25(OH) 2 D3, 25(OH)D3 and PTH levels of colorectal carcinoma patients to those of healthy controls and found that serum vitamin D metabolite levels did not correlate with gender, age, tumor localization or histologic grade (43).

\section{Studies on deficiency and insufficiency of serum vitamin $D$ in other and multiple cancer sites}

Table III describes studies investigating the deficiency and insufficiency of serum vitamin D in patients with other as well as multiple cancer sites. The studies are arranged chronologically by the year of publication.

Hofmann et al evaluated within-person variability in 25(OH)D concentrations across serum samples collected at three time points over a 5-year period among 29 participants in the Prostate, Lung, Colorectal and Ovarian Cancer Screening Trial. They observed relatively low within-subject variability and fairly high correlations in $25(\mathrm{OH}) \mathrm{D}$ measured from samples collected at study baseline, after 1 year and after 5 years. These findings suggest that serum 25(OH)D concentration at a single time point may be a useful biomarker of long-term vitamin D status in population-based studies of various diseases (44). Laney et al, in a recent pilot study, found the levels of vitamin D and the rates of vitamin D deficiency to be similar between patients with thyroid nodules, thyroid cancer in remission and active thyroid cancer. Vitamin D deficiency $(<30 \mathrm{ng} / \mathrm{ml})$ was not significantly different between groups and was not affected by season of measurement, age or cancer stage. This study did not find any association between vitamin D deficiency and the histologic type of thyroid cancer, the stage of thyroid cancer or the status of the disease (45). Thill et al evaluated the expression of the prostaglandin (PG)-metabolizing enzymes COX-2 and 15-hydroxyprostaglandin dehydrogenase (15-PGDH) compared to the vitamin $\mathrm{D}$ receptor (VDR) in benign and malignant ovarian tissues. Additionally, they determined the $25(\mathrm{OH})_{2} \mathrm{D} 3$ serum levels. They detected significantly higher expression of the PG-metabolizing enzymes 15-PGDH and COX-2 in malignant tissue, and $\mathrm{PGE}_{2}$ serum levels were 2-fold higher in tumor patients. They found mean serum vitamin $\mathrm{D}$ levels to be $29.15 \pm 2.74 \mathrm{ng} / \mathrm{ml}$ in healthy women and $25.23 \pm 1.57 \mathrm{ng} / \mathrm{ml}$ in women with ovarian cancer (46).

McCombie et al recruited 25 patients with a history of non-melanoma skin cancer, who were not taking vitamin D or calcium supplements, from outpatient dermatology clinics at Royal Prince Alfred Hospital, Sydney. Using the target value of $20 \mathrm{ng} / \mathrm{ml}, 12$ participants $(48 \%)$ were vitamin D deficient at the end of winter, compared to one (4\%) at the end of summer. Despite mean reported daily sun exposure falling within recommended guidelines, half of the participants were vitamin $\mathrm{D}$ deficient at the end of winter, with almost all demonstrating reductions in winter $25(\mathrm{OH}) \mathrm{D}$ levels $(47)$. Nurnberg et al examined the association between serum 


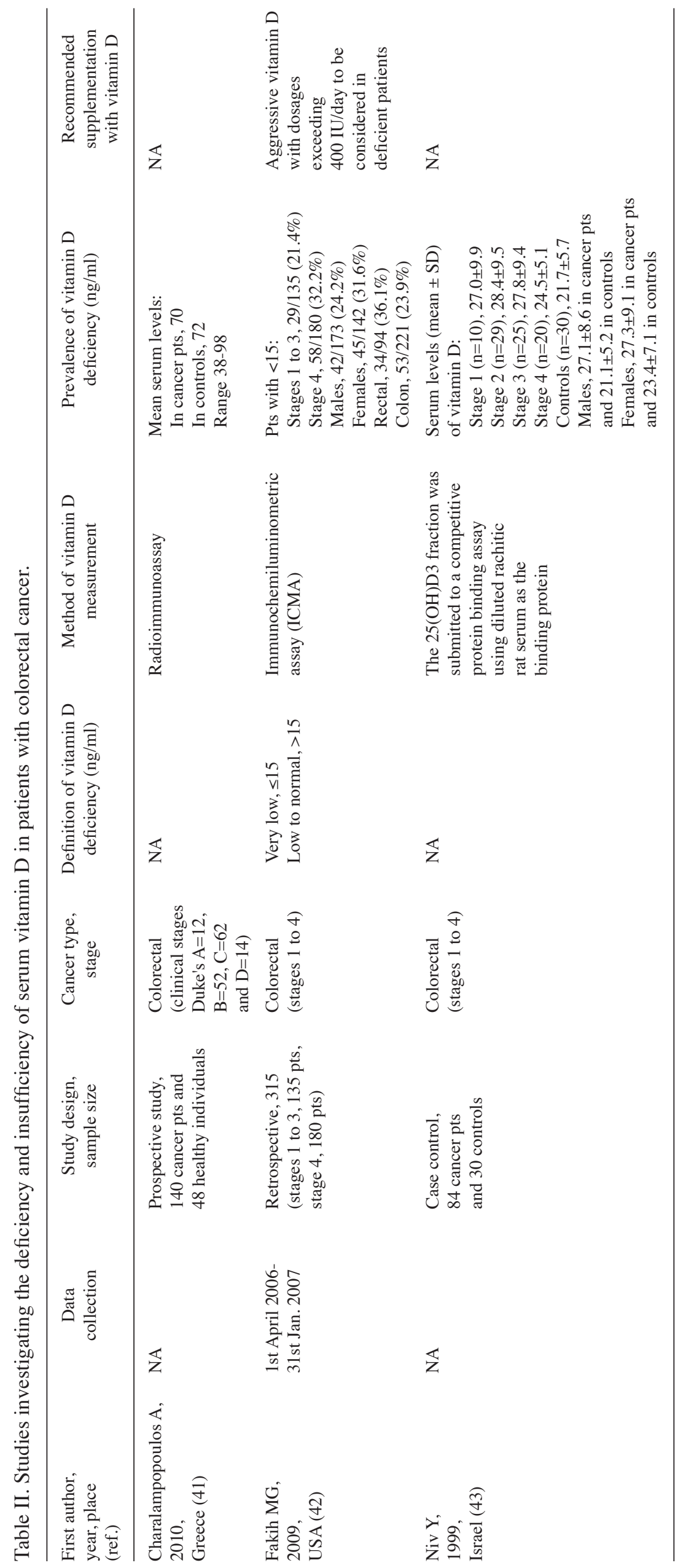


25(OH)D levels and clinical and histopathological data among 205 patients with malignant melanoma. Serum 25(OH)D levels were significantly reduced in stage IV melanoma patients as compared to stage I melanoma patients $(\mathrm{P}=0.006)$. They also found a trend towards a greater tumor thickness with low $(<10 \mathrm{ng} / \mathrm{ml})$ serum 25(OH)D levels (median $2.55 \mathrm{~mm}$ ) as compared to those with $25(\mathrm{OH}) \mathrm{D}$ serum levels $>20 \mathrm{ng} /$ $\mathrm{ml}$ (median $1.5 \mathrm{~mm}$ ). Lastly, the patients with low 25(OH)D serum levels $(<10 \mathrm{ng} / \mathrm{ml})$ had earlier distant metastatic disease (median 24.37 months) as compared to those with 25(OH)D serum levels $>20 \mathrm{ng} / \mathrm{ml}$ (median 29.47 months) (48). Trump et $a l$ in a case control study found the frequency of vitamin D deficiency $(<20 \mathrm{ng} / \mathrm{ml})$ and insufficiency $(20-31 \mathrm{ng} / \mathrm{ml})$ to be 40 and $32 \%$, respectively in men with recurrent prostate cancer. Among men with localized prostate cancer, $18 \%$ were deficient, $50 \%$ were insufficient and $32 \%$ were normal. Among controls, $31 \%$ were deficient, $40 \%$ were insufficient and $29 \%$ were normal. This study clearly showed a high frequency of abnormally low 25-OH vitamin D levels among patients with prostate cancer, regardless of disease status or treatment (49).

Badros et al measured the prevalence of vitamin D deficiency in 100 multiple myeloma (MM) patients and showed that $40 \%$ had vitamin D deficiency, defined by serum $25(\mathrm{OH})$ D levels < $14.4 \mathrm{ng} / \mathrm{ml}$. Thirty-five percent had vitamin D insufficiency, defined by levels of 14.4-30 ng/ml. Only $25 \%$ had sufficient levels, defined as $>30 \mathrm{ng} / \mathrm{ml}$. They found no significant correlation between vitamin D status and MM activity (remission, relapsed or newly diagnosed), presence or absence of lytic bone disease and/or fractures or history of osteonecrosis of the jaw (50). Everett et al conducted a study in patients at the Lynchburg Hematology-Oncology Clinic, where the number of patients tested for the first time from May to September were 86,89, 72, 59 and 81, respectively. Of those tested, most had vitamin D levels $<30 \mathrm{ng} / \mathrm{ml}$ (75.4, 84.1, $66.6,69.3$ and $63 \%$, respectively). The study concluded that oncology clinicians must be aware of the potential negative effects of low vitamin D levels in their patient populations and should consider testing for and treating this deficiency or insufficiency in their practices (51). Reinhold et al measured the serum $25(\mathrm{OH}) \mathrm{D}$ concentration among subjects in a German polyclinic. In $>50 \%$ of these 174 subjects, the $25(\mathrm{OH})$ D concentration was $<20 \mathrm{ng} / \mathrm{ml}$. In most subject groups, a seasonal decrease of $25(\mathrm{OH}) \mathrm{D}$ concentration was observed during the winter period. An age-related decrease in such a concentration was also observed in subjects with prostatic hyperplasia examined in the late summer/early autumn period and in female cancer subjects, at the exclusion of patients with breast cancer. In the latter patients, however, a positive correlation prevailed between age and $25(\mathrm{OH}) \mathrm{D}$ concentration (52).

Hollender et al carried out a study in patients treated for gastric non-Hodgkin's lymphoma and found that of 33 patients out of 40 who met for follow-up examination after treatment, 17 patients had a partial gastrectomy (PG), 9 a total gastrectomy (TG) and 7 patients were not operated on. The patients in the TG group had significant weight loss. Moreover, the patients in the TG group had a lower serum vitamin D than the other groups. They further concluded that when surgery is necessary, a PG should be performed when possible and that patients should receive dietary advice before leaving the hospital after surgery and possibly life-long iron, calcium, vitamin D, folate and vitamin B12 supplementation (53). Lammert et al measured serum $25(\mathrm{OH}) \mathrm{D}$ concentrations in 55 patients with neurofibromatosis 1 (NF1) and 58 healthy controls. The mean serum 25(OH)D concentration was $14.0 \mathrm{ng} / \mathrm{ml}$ among the patients with NF1 compared to $31.4 \mathrm{ng} / \mathrm{ml}$ among the healthy controls $(\mathrm{P}=0.0001)$. The strong correlation observed between NF1 patients and low serum vitamin D concentrations was unexpected. It is possible that patients with NF1 with multiple dermal neurofibromas are more likely to cover their skin and thus receive less sunlight than patients with NF1 who have fewer dermal tumors (54). Plant and Tisman demonstrated that out of 60 patients of different cancer types, when $25(\mathrm{OH})$ D insufficiency was defined as a serum level of $<30 \mathrm{ng} / \mathrm{ml}$, $43(72 \%)$ patients were found to be insufficient. Even at the lower definition of insufficiency, $<20 \mathrm{ng} / \mathrm{ml}, 24$ of 60 patients (40\%) were insufficient. This study showed that the deficiency of vitamin D (72\%) was prevalent among newly diagnosed patients with cancer and could play a role in cancer development and host response to tumor and therapy (55).

Reichrath and Querings tested the hypothesis whether low serum levels of $25(\mathrm{OH}) \mathrm{D}$ may be a risk factor for the development of malignant melanoma. This study found that the mean $(23.563 \mathrm{ng} / \mathrm{ml})$ and median $(24.591 \mathrm{ng} / \mathrm{ml}) 25(\mathrm{OH})$ $\mathrm{D}$ serum levels of these melanoma patients were in the normal range $(20-50 \mathrm{ng} / \mathrm{ml})$, indicating no relationship between serum levels of $25(\mathrm{OH}) \mathrm{D}$ and development of malignant melanoma (56). Tangpricha et al determined the prevalence of vitamin $\mathrm{D}$ deficiency in an outpatient cancer care clinic at Boston University Medical Center. A control group of healthy adults without cancer was recruited the previous year during the same months. Of the 56 patients with cancer, 27 (48\%) had vitamin $\mathrm{D}$ deficiency $(\leq 20 \mathrm{ng} / \mathrm{ml})$, in comparison to only 6 $(12 \%)$ of the 50 healthy control subjects (57).

\section{Discussion}

Vitamin D inadequacy constitutes a largely unrecognized epidemic in many populations worldwide (58-60). It has been reported in healthy children (61), adolescents (62) and adults $(63,64)$. Lower vitamin D levels are associated with advancing age $(65,66)$, female gender (67-69), history of diabetes $(70)$, hypertension, greater body mass index (71) and a lower estimated glomerular filtration rate (72). Vitamin D levels vary by region and are greater in summer than in winter months $(73,74)$. Higher skin melanin levels increase the risk of vitamin D deficiency. Of late, there has been an increasing interest in the role of vitamin D in cancer etiology and outcomes and, as a result, several studies have reported the prevalence of vitamin D deficiency and insufficiency in patients with different types of cancer. However, the existing studies on this topic differ from each other with respect to study population, sample size, study design, definition of vitamin D deficiency used and method of vitamin D assessment. Therefore, we conducted a qualitative review of the existing literature with the goal of understanding the current status and providing insights on the directions for future research.

Twenty-seven studies were reviewed and most $(n=12)$ were conducted prospectively to assess the $25(\mathrm{OH}) \mathrm{D}$ serum levels in different types of cancer patients. The other studies included retrospective $(n=3)$, cross-sectional $(n=2)$, case series 


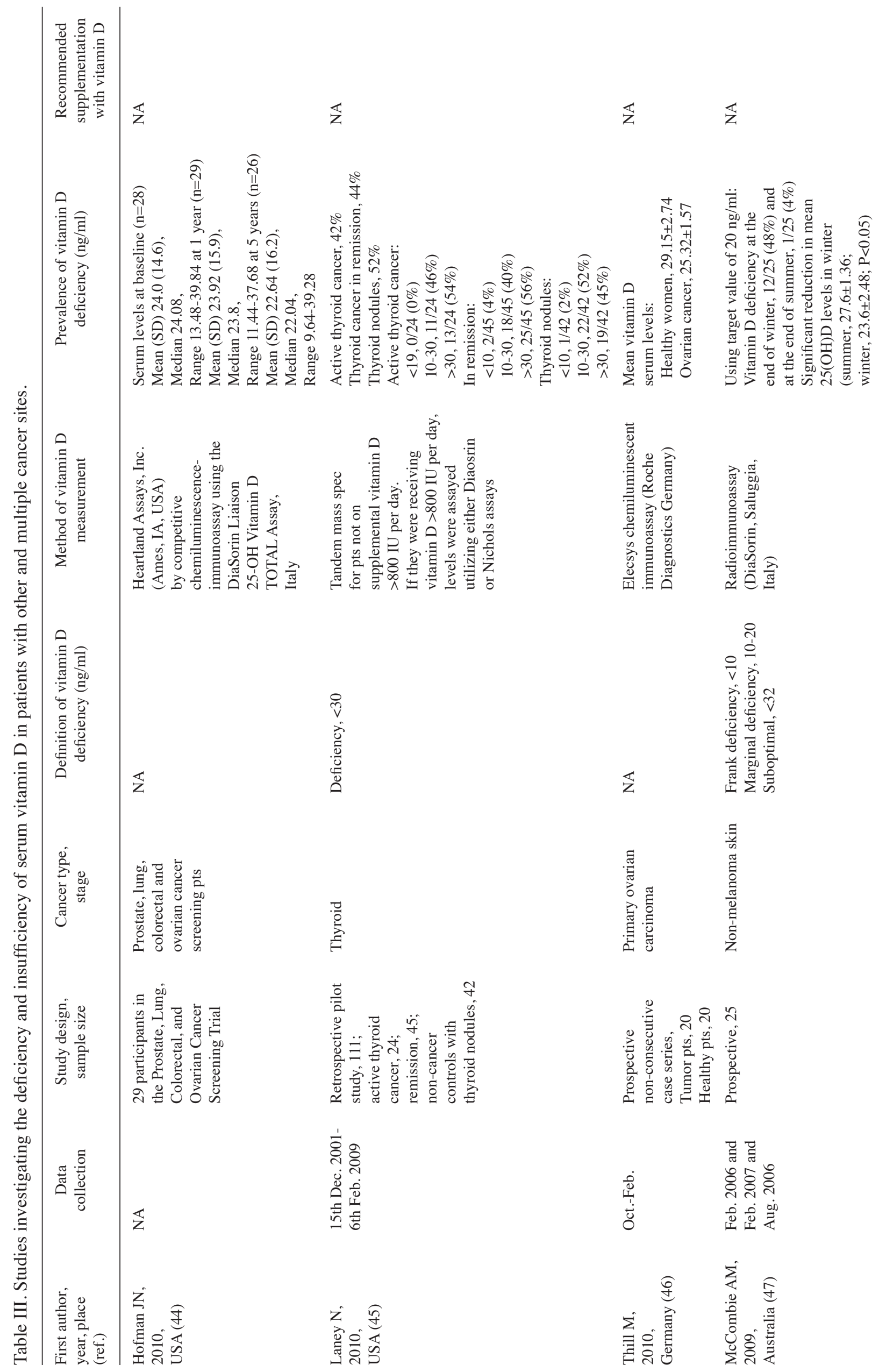




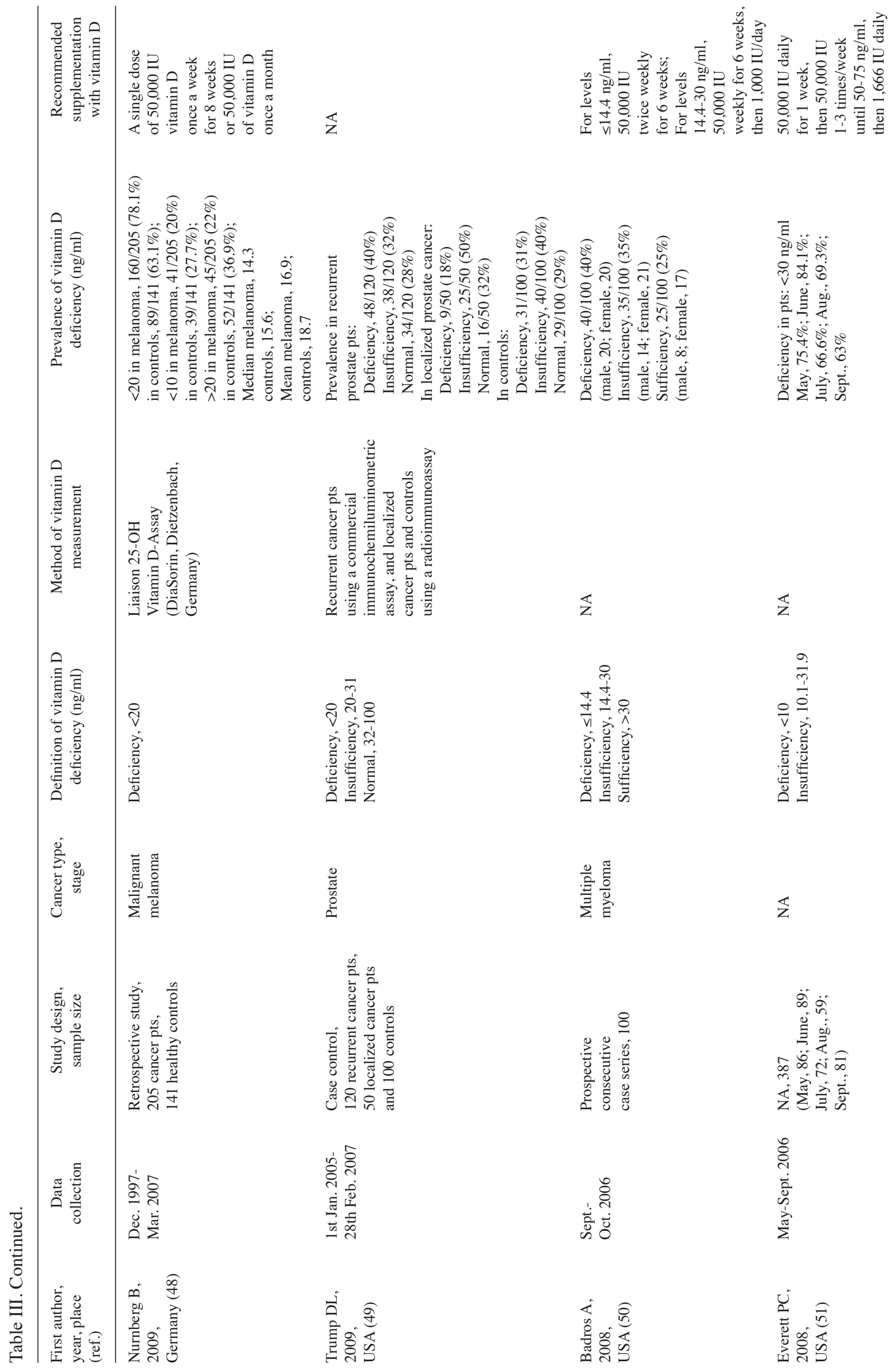




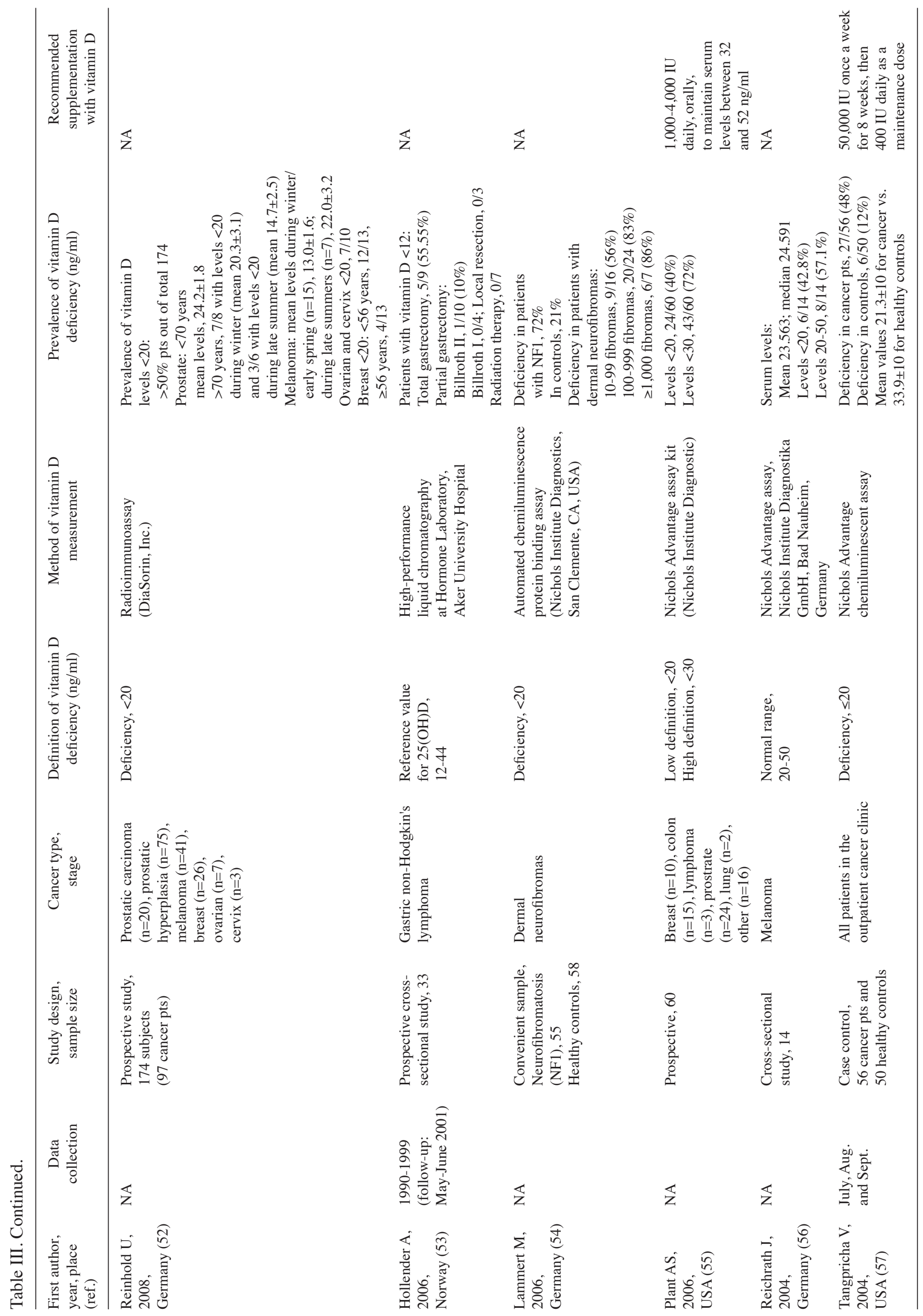


$(n=1)$, convenience sample $(n=1)$ and case-control study $(n=2)$ designs. Furthermore, two studies used data from other existing studies with a larger sample size, such as The Health, Eating, Activity, and Lifestyle (HEAL) study and the Prostate, Lung, Colorectal and Ovarian Cancer Screening Trial (PLCO). Ten studies were conducted in breast cancer patients exclusively, three on colorectal, two on melanoma and one each on gastric lymphoma, multiple myeloma, neurofibroma, prostate, ovarian, thyroid and non-melanoma skin cancers, while the remaining five studies were based on a heterogenous group of cancer patients.

While comparing the cut-off levels for definition of vitamin $\mathrm{D}$ deficiency, we found that the majority of the studies $(\mathrm{n}=11)$ used a threshold of $<20 \mathrm{ng} / \mathrm{ml}$. The other studies used different cut-offs ranging from 10 to $32 \mathrm{ng} / \mathrm{ml}$. Most of the studies $(n=10)$ measured the serum $25(\mathrm{OH}) \mathrm{D}$ levels using the radioimmunoassay, while some of the other studies used Nichols Advantage assay kit $(n=3)$, high-performance liquid chromatography $(n=1)$, protein binding assay $(n=2)$, competitive immunoluminometric direct assay $(n=2)$ and chemiluminescent immunoassay $(n=2)$. Many of these studies showed a prevalence of vitamin D deficiency $>70 \%(31,34-37,48,51,54)$. A few studies $(n=9)$ reported a prevalence rate between 40 and $70 \%$, while the other studies $(n=4)$ reported rates lower than $40 \%$. Six studies reported only the mean serum vitamin D levels.

Some studies provided an estimate of vitamin D deficiency across stage of the disease, as well as season of vitamin D assessment. An inverse correlation between serum levels of vitamin $\mathrm{D}$ and carcinoma stage was demonstrated in three studies $(40,42,43)$. According to these studies, the serum levels of $25(\mathrm{OH}) \mathrm{D}$ were significantly higher in patients with early-stage cancer than in those with locally advanced or metastatic disease. An exception to this observation was one study on ovarian cancer patients (39) in which stage III and IV carcinoma patients had higher $25(\mathrm{OH}) \mathrm{D}$ serum levels than in stage I and II patients. A few studies also showed lower serum $25(\mathrm{OH}) \mathrm{D}$ levels in blood samples drawn during winter $(31,47,52)$ depicting variations in the prevalence rate according to sun exposure. Some studies also reported results by gender. Badros et al reported an equal distribution of males and females with deficient serum $25(\mathrm{OH}) \mathrm{D}$ levels among patients with multiple myeloma (50). Similarly, in colorectal cancer patients, Fakih et al reported almost equal mean $25(\mathrm{OH})$ D levels among males and females (42). Moreover, Niv et al reported a higher prevalence rate of deficiency in females (31.6\%) than in males (24.2\%) among colorectal cancer patients (43). In addition, a study by Crew et al also reported that vitamin D deficiency was slightly less common in white women $(66 \%)$ compared to black $(80 \%)$ and Hispanic $(84 \%)$ women (34).

Some studies also reported on supplementation recommendations to address vitamin D deficiency. Most studies suggested an aggressive vitamin D replacement strategy, including 50,000 IU weekly $(n=3)$ or 50,000 IU twice a week $(n=1)$ or 50,000 IU 1-3 times a week $(n=1)$, while the others suggested a daily dose of vitamin D, including 2,000 IU ( $n=2)$ or 3,000 IU $(n=1)$ orally. Thus, the recommended dosage by all studies ranged from 8,000 to $50,000 \mathrm{IU}$, one to three times a week for deficient patients. A few studies also suggested a maintenance dose regime ranging from 400 to 2,000 IU daily after the serum levels were raised to normal.

In conclusion, this review confirms a high prevalence of vitamin D deficiency in multiple cancer sites. Healthcare providers play important roles in disease prevention, health promotion and education. Since vitamin D deficiency is a widespread public health issue linked to cancer and other health risks, healthcare providers should not ignore this easily correctable condition. Therefore, evaluation of vitamin D levels and vitamin D supplementation for deficient individuals should be taken into consideration, while providing anticancer treatment. Optimizing vitamin D levels provides 'win-win' benefits of correcting vitamin $\mathrm{D}$ deficiency, promoting bone health and potentially reducing cancer risks. Given the variation found in the studies in this review regarding the levels of $25(\mathrm{OH}) \mathrm{D}$ used to define deficiency, the method used to evaluate $25(\mathrm{OH}) \mathrm{D}$, and even recommendations for supplementation for deficient individuals, additional research needs to be carried out to determine acceptable standards in these areas.

Since the prevalence of vitamin D deficiency appears to be high in multiple cancer sites, future research evaluating the impact of correcting and maintaining adequate vitamin D levels on survival outcomes and secondary prevention of cancer is essential.

\section{Acknowledgements}

This study was funded by the Cancer Treatment Centers of America ${ }^{\circledR}$.

\section{References}

1. Holick MF: Vitamin D deficiency. N Engl J Med 357: 266-281, 2007.

2. Adams JS and Hewison M: Update in vitamin D. J Clin Endocrinol Metab 95: 471-478, 2010.

3. Hollis BW: Assessment of circulating $25(\mathrm{OH}) \mathrm{D}$ and $1,25(\mathrm{OH}) 2 \mathrm{D}$ : emergence as clinically important diagnostic tools. Nutr Rev 65: S87-S90, 2007.

4. Hollis BW: Circulating 25-hydroxyvitamin D levels indicative of vitamin D sufficiency: implications for establishing a new effective dietary intake recommendation for vitamin D. J Nutr 135: 317-322, 2005.

5. Dawson-Hughes B, Heaney RP, Holick MF, Lips P, Meunier PJ and Vieth R: Estimates of optimal vitamin D status. Osteoporos Int 16: 713-716, 2005.

6. Bischoff-Ferrari HA: Optimal serum 25-hydroxyvitamin D levels for multiple health outcomes. Adv Exp Med Biol 624: 55-71, 2008.

7. Dusso AS, Brown AJ and Slatopolsky E: Vitamin D. Am J Physiol Renal Physiol 289: F8-F28, 2005.

8. Holick MF: Resurrection of vitamin D deficiency and rickets. J Clin Invest 116: 2062-2072, 2006.

9. Dalhoff K, Dancey J, Astrup L, et al: A phase II study of the vitamin D analogue Seocalcitol in patients with inoperable hepatocellular carcinoma. Br J Cancer 89: 252-257, 2003.

10. Diaz GD, Paraskeva C, Thomas MG, Binderup L and Hague A: Apoptosis is induced by the active metabolite of vitamin D3 and its analogue EB1089 in colorectal adenoma and carcinoma cells: possible implications for prevention and therapy. Cancer Res 60: 2304-2312, 2000.

11. Vandewalle B, Wattez N and Lefebvre J: Effects of vitamin D3 derivatives on growth, differentiation and apoptosis in tumoral colonic HT 29 cells: possible implication of intracellular calcium. Cancer Lett 20: 99-106, 1995.

12. Scaglione-Sewell BA, Bissonnette M, Skarosi S, Abraham C and Brasitus TA: A vitamin D3 analog induces a G1-phase arrest in CaCo-2 cells by inhibiting cdk2 and cdk6: roles of cyclin E, p21Waf1, and p27Kip1. Endocrinology 141: 3931-3939, 2000. 
13. Fernandez-Garcia NI, Palmer HG, Garcia M, et al: 1alpha,25Dihydroxyvitamin D3 regulates the expression of Id1 and Id2 genes and the angiogenic phenotype of human colon carcinoma cells. Oncogene 24: 6533-6544, 2005.

14. Evans SR, Shchepotin EI, Young H, Rochon J, Uskokovic M and Shchepotin IB: 1,25-dihydroxyvitamin D3 synthetic analogs inhibit spontaneous metastases in a 1,2-dimethylhydrazineinduced colon carcinogenesis model. Int J Oncol 16: 1249-1254, 2000.

15. Lamprecht SA and Lipkin M: Cellular mechanisms of calcium and vitamin D in the inhibition of colorectal carcinogenesis. Ann NY Acad Sci 952: 73-87, 2001

16. Ahn J, Peters U, Albanes D, et al: Serum vitamin D concentration and prostate cancer risk: a nested case-control study. J Nat Cancer Inst 100: 796-804, 2008

17. Mucci LA and Spiegelman D: Vitamin D and prostate cancer risk - a less sunny outlook? J Natl Cancer Inst 100: 796-804, 2008.

18. Abbas S, Linseisen J, Slanger T, Kropp S, Mutschelknauss EJ, Flesch-Janys D and Chang-Claude J: Serum 25-hydroxyvitamin D and risk of post-menopausal breast cancer - results of a large case-control study. Carcinogenesis 29: 93-99, 2008.

19. Freedman DM, Looker AC, Chang SC and Graubard BI: Prospective study of serum vitamin D and cancer mortality in the United States. J Natl Cancer Inst 99: 1594-1602, 2007.

20. Giovannucci E, Liu Y, Rimm EB, Hollis BW, Fuchs CS, Stampfer MJ and Willett WC: Prospective study of predictors of vitamin D status and cancer incidence and mortality in men. J Natl Cancer Inst 98: 451-459, 2006.

21. Heist RS, Zhou W, Wang Z, et al: Circulating 25-hydroxyvitamin D, VDR polymorphisms, and survival in advanced non-small-cell lung cancer. J Clin Oncol 26: 5596-5602, 2008.

22. Ng K, Meyerhardt JA, Wu K, Feskanich D, Hollis BW, Giovannucci EL and Fuchs CS: Circulating 25-hydroxyvitamin D levels and survival in patients with colorectal cancer. J Clin Oncol 26: 2984-2991, 2008.

23. Pilz S, Dobnig H, Winklhofer-Roob B, et al: Low serum levels of 25-hydroxyvitamin D predict fatal cancer in patients referred to coronary angiography. Cancer Epidemiol Biomarkers Prev 17: 1228-1233, 2008.

24. Tretli S, Hernes E, Berg JP, Hestvik UE and Robsahm TE: Association between serum 25(OH)D and death from prostate cancer. Br J Cancer 100: 450-454, 2009.

25. Zhou W, Heist RS, Liu G, et al: Circulating 25-hydroxyvitamin D levels predict survival in early-stage non-small-cell lung cance patients. J Clin Oncol 25: 479-485, 2007.

26. Stolzenberg-Solomon RZ, Vieth R, Azad A, Pietinen $P$ Taylor PR, Virtamo J and Albanes D: A prospective nested casecontrol study of vitamin D status and pancreatic cancer risk in male smokers. Cancer Res 66: 10213-10219, 2006.

27. Grant WB: An estimate of premature cancer mortality in the U.S. due to inadequate doses of solar ultraviolet-B radiation. Cancer 94: 1867-1875, 2002.

28. Feskanich D, Ma J, Fuchs CS, Kirkner GJ, Hankinson SE, Hollis BW and Giovannucci EL: Plasma vitamin D metabolites and risk of colorectal cancer in women. Cancer Epidemiol Biomarkers Prev 13: 1502-1508, 2004.

29. Pritchard RS, Baron JA and Gerhardsson DV: Dietary calcium, vitamin D, and the risk of colorectal cancer in Stockholm, Sweden. Cancer Epidemiol Biomarkers Prev 5: 897-900, 1996.

30. Giovannucci E: The epidemiology of vitamin D and cancer incidence and mortality: a review (United States). Cancer Causes Control 16: 83-95, 2005.

31. Nogues X, Servitja S, Pena MJ, et al: Vitamin D deficiency and bone mineral density in postmenopausal women receiving aromatase inhibitors for early breast cancer. Maturitas 66 : 291-297, 2010

32. Neuhouser Ml, Bernstein L, Hollis BW, et al: Serum vitamin D and breast density in breast cancer survivors. Cancer Epidemiol Biomarkers Prev 19: 412-417, 2010.

33. Khan QJ, Reddy PS, Kimler BF, et al: Effect of vitamin D supplementation on serum 25-hydroxy vitamin D levels, joint pain, and fatigue in women starting adjuvant letrozole treatment for breast cancer. Breast Cancer Res Treat 119: $111-118,2010$

34. Crew KD, Shane E, Cremers S, McMahon DJ, Irani D and Hershman DL: High prevalence of vitamin D deficiency despite supplementation in premenopausal women with breast cancer undergoing adjuvant chemotherapy. J Clin Oncol 27: 2151-2156, 2009 .
35. Rainville C, Khan Y and Tisman G: Triple negative breast cancer patients presenting with low serum vitamin D levels: a case series. Cases J 2: 8390, 2009.

36. Waltman NL, Ott CD, Twiss JJ, Gross GJ and Lindsey AM: Vitamin D insufficiency and musculoskeletal symptoms in breast cancer survivors on aromatase inhibitor therapy. Cancer Nurs 32: 143-150, 2009.

37. Neuhouser Ml, Sorensen B, Hollis BW, et al: Vitamin D insufficiency in a multiethnic cohort of breast cancer survivors. Am J Clin Nutr 88: 133-139, 2008.

38. Wang-Gillam A, Miles DA and Hutchins LF: Evaluation of vitamin D deficiency in breast cancer patients on bisphosphonates. Oncologist 13: 821-827, 2008.

39. De Lyra EC, da Silva IA, Katayama Ml, Brentani MM, Nonogaki S, Goes JC and Folgueira MA: 25(OH)D3 and $1,25(\mathrm{OH}) 2 \mathrm{D} 3$ serum concentration and breast tissue expression of 1alpha-hydroxylase, 24-hydroxylase and vitamin D receptor in women with and without breast cancer. J Steroid Biochem Mol Biol 100: 184-192, 2006

40. Palmieri C, MacGregor T, Girgis S and Vigushin D: Serum 25-hydroxyvitamin D levels in early and advanced breast cancer. J Clin Pathol 59: 1334-1336, 2006.

41. Charalampopoulos A, Charalabopoulos A, Batistatou A, et al: Parathormone and $1,25(\mathrm{OH}) 2 \mathrm{D} 3$ but not $25(\mathrm{OH}) \mathrm{D} 3$ serum levels, in an inverse correlation, reveal an association with advanced stages of colorectal cancer. Clin Exp Med 10: 69-72, 2010.

42. Fakih MG, Trump DL, Johnson CS, Tian L, Muindi J and Sunga AY: Chemotherapy is linked to severe vitamin D deficiency in patients with colorectal cancer. Int J Colorectal Dis 24: 219-224, 2009

43. Niv Y, Sperber AD, Figer A, Igael D, Shany S, Fraser G and Schwartz B: In colorectal carcinoma patients, serum vitamin D levels vary according to stage of the carcinoma. Cancer 86: 391-397, 1999.

44. Hofmann JN, Yu K, Horst RL, Hayes RB and Purdue MP: Long-term variation in serum 25 -hydroxyvitamin $\mathrm{D}$ concentration among participants in the Prostate, Lung, Colorectal, and Ovarian Cancer Screening Trial. Cancer Epidemiol Biomarkers Prev 19: 927-931, 2010.

45. Laney N, Meza J, Lyden E, Erickson J, Treude K and Goldner W: The prevalence of vitamin D deficiency is similar between thyroid nodule and thyroid cancer patients. Int J Endocrinol: 805716, 2010 (E-pub ahead of print)

46. Thill M, Fischer D, Kelling K, et al: Expression of vitamin D receptor (VDR), cyclooxygenase-2 (COX-2) and 15-hydroxyprostaglandin dehydrogenase (15-PGDH) in benign and malignant ovarian tissue and 25-hydroxycholecalciferol $(25(\mathrm{OH}(2)) \mathrm{D}(3))$ and prostaglandin E(2) (PGE(2)) serum level in ovarian cancer patients. J Steroid Biochem Mol Biol 121: 387-390, 2010.

47. McCombie AM, Mason RS and Damian DL: Vitamin D deficiency in Sydney skin cancer patients. Med J Aust 190: 102, 2009.

48. Nurnberg B, Graber S, Gartner B, et al: Reduced serum 25-hydroxyvitamin D levels in stage IV melanoma patients. Anticancer Res 29: 3669-3674, 2009.

49. Trump DL, Chadha MK, Sunga AY, et al: Vitamin D deficiency and insufficiency among patients with prostate cancer. BJU Int 104: 909-914, 2009.

50. Badros A, Goloubeva O, Terpos E, Milliron T, Baer MR and Streeten E: Prevalence and significance of vitamin $\mathrm{D}$ deficiency in multiple myeloma patients. Br J Haematol 142: 492-494, 2008.

51. Everett PC: The prevalence of vitamin D deficiency and insufficiency in a hematology-oncology clinic. Clin J Oncol Nurs 12: 33-35, 2008.

52. Reinhold U, Schmitz B, Kurbacher C, Nagel W, Schmidt M and Malaisse WJ: Circulating 25-hydroxyvitamin D concentration in German cancer patients. Oncol Rep 20: 1539-1543, 2008.

53. Hollender A, Bjoro T, Otto KK, Kvaloy SO, Nome O and Holte H: Vitamin D deficiency in patients operated on for gastric lymphoma. Scand J Gastroenterol 41: 673-681, 2006.

54. Lammert M, Friedman JM, Roth HJ, et al: Vitamin D deficiency associated with number of neurofibromas in neurofibromatosis 1 . J Med Genet 43: 810-813, 2006.

55. Plant AS and Tisman G: Frequency of combined deficiencies of vitamin D and holotranscobalamin in cancer patients. Nutr Cancer 56: 143-148, 2006.

56. Reichrath J and Querings K: No evidence for reduced 25-hydroxyvitamin D serum level in melanoma patients. Cancer Causes Control 15: 97-98, 2004 
57. Tangpricha V, Colon NA, Kaul H, et al: Prevalence of vitamin D deficiency in patients attending an outpatient cancer care clinic in Boston. Endocr Pract 10: 292-293, 2004

58. Gaugris S, Heaney RP, Boonen S, Kurth H, Bentkover JD and Sen SS: Vitamin D inadequacy among post-menopausal women: a systematic review. QJM 98: 667-676, 2005.

59. Isaia G, Giorgino R, Rini GB, Bevilacqua $M$, Maugeri D and Adami S: Prevalence of hypovitaminosis D in elderly women in Italy: clinical consequences and risk factors. Osteoporos Int 14: 577-582, 2003

60. Plotnikoff GA and Quigley JM: Prevalence of severe hypovitaminosis D in patients with persistent, nonspecific musculoskeletal pain. Mayo Clin Proc 78: 1463-1470, 2003.

61. Rovner AJ and O'Brien KO: Hypovitaminosis D among healthy children in the United States: a review of the current evidence. Arch Pediatr Adolesc Med 162: 513-519, 2008.

62. Gordon CM, DePeter KC, Feldman HA, Grace E and Emans SJ Prevalence of vitamin D deficiency among healthy adolescents. Arch Pediatr Adolesc Med 158: 531-537, 2004.

63. Looker AC, Dawson-Hughes B, Calvo MS, Gunter EW and Sahyoun NR: Serum 25-hydroxyvitamin D status of adolescents and adults in two seasonal subpopulations from NHANES III Bone 30: 771-777, 2002.

64. Tangpricha V, Pearce EN, Chen TC and Holick MF: Vitamin D insufficiency among free-living healthy young adults. Am J Med 112: 659-662, 2002.

65. Lips P: Vitamin D deficiency and secondary hyperparathyroidism in the elderly: consequences for bone loss and fractures and therapeutic implications. Endocr Rev 22: 477-501, 2001.
66. McKenna MJ: Differences in vitamin D status between countries in young adults and the elderly. Am J Med 93: 69-77, 1992.

67. Das G, Crocombe S, McGrath M, Berry JL and Mughal MZ: Hypovitaminosis D among healthy adolescent girls attending an inner city school. Arch Dis Child 91: 569-572, 2006.

68. Lips P, Duong T, Oleksik A, Black D, Cummings S, Cox D and Nickelsen T: A global study of vitamin D status and parathyroid function in postmenopausal women with osteoporosis: baseline data from the multiple outcomes of raloxifene evaluation clinical trial. J Clin Endocrinol Metab 86: 1212-1221, 2001.

69. Sullivan SS, Rosen CJ, Halteman WA, Chen TC and Holick MF: Adolescent girls in Maine are at risk for vitamin D insufficiency. J Am Diet Assoc 105: 971-974, 2005.

70. Yanoff LB, Parikh SJ, Spitalnik A, et al: The prevalence of hypovitaminosis D and secondary hyperparathyroidism in obese Black Americans. Clin Endocrinol 64: 523-529, 2006.

71. Bell NH, Epstein S, Greene A, Shary J, Oexmann MJ and Shaw S: Evidence for alteration of the vitamin D-endocrine system in obese subjects. J Clin Invest 76: 370-373, 1985.

72. De Boer IH, Ioannou GN, Kestenbaum B, Brunzell JD and Weiss NS: 25-Hydroxyvitamin D levels and albuminuria in the Third National Health and Nutrition Examination Survey (NHANES III). Am J Kidney Dis 50: 69-77, 2007.

73. Chatfield SM, Brand C, Ebeling PR and Russell DM: Vitamin D deficiency in general medical inpatients in summer and winter. Intern Med J 37: 377-382, 2007.

74. Olmez D, Bober E, Buyukgebiz A and Cimrin D: The frequency of vitamin D insufficiency in healthy female adolescents. Acta Paediatr 95: 1266-1269, 2006. 